\title{
nature
}

\section{Keeping religion out of science class}

\author{
President Bush's endorsement of 'intelligent design' has sparked a national debate in which scientists are \\ well positioned to prevail.
}

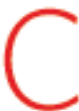
omments made last week by President George W. Bush have encouraged advocates of 'intelligent design', the idea that a hidden hand must lie somewhere behind the evolution of life. But the scientific community has responded energetically and effectively to Bush's statements. If researchers persevere, they can win this argument and keep religion out of the biology classroom.

In an informal 90-minute interview with newspaper reporters from his home state of Texas on 1 August, Bush talked at length about everything from abortion to illegal immigration. When asked about his view of intelligent design, the president was hesitant at first, re-iterating that, as governor of Texas, he had supported the right of local school boards to choose what is taught in the classroom. Prodded further to give an opinion, Bush said: ' I'm not suggesting you're asking me whether or not people ought to be exposed to different ideas, and the answer is yes."

A great deal has been made of the president's off-the-cuffendorsement of intelligent design. But it is worth noting the hesitancy of his comments: he didn't even mention intelligent design by name. Bush is a self-proclaimed evangelical Christian, and religious conservatives are often credited with helping him win last year's election. But he knows perfectly well that the introduction of religious ideas into science class is a potentially explosive issue in US politics - and not necessarily one that works in his favour.

The teaching of creationism in schools has been energetically advocated in parts of the United States for decades, but it has rarely help politicians to win elections, even in the heartland. Take Kansas, whose school board sought in 1999 to restrict the teaching of evolution in public schools. A vocal outcry by scientists, business leaders and others soon led to the electoral defeat of the board members in question and a repeal of the restrictions (see Nature 406, 552; 2000).

Those Republicans who anticipate an encounter with the electorate are therefore cautious about the open embrace of intelligent design. Senator Rick Santorum (Republican, Pennsylvania), for example, is a Catholic and one of the most conservative members of the Senate, who faces a tough re-election battle next year. Just after Bush's remarks, he forthrightly declared: "I'm not comfortable with intelligent design being taught in the science classroom." Perhaps Santorum judges, wisely, that otherwise-conservative voters in the suburbs of Philadelphia and Pittsburgh would draw the line at backing a senator who wants to teach creationism to little Brad and Britney in biology class.

Even hard-line creationists are aware of the political price of appearing to be against science in a nation that puts so much stock in it. Part of the idea of intelligent design, of course, is subterfuge, an attempt to introduce religion under the guise of science. In Kansas, after the
"Part of the idea of intelligent design is introduce religion under the guise of science." subterfuge, an attempt to last row died down, a more conservative school board was elected once again, and now may approve the inclusion of intelligent design in its school curriculum. The progress of this effort - which scientists have once again made a concerted effort to oppose - will be a bellwether for the rest of the country.

As we report on page 761, scientific leaders have responded effectively to Bush's ill-advised comments. Researchers from a range of disciplines have spoken out vigorously, making it clear that the president's apparent willingness to allow intelligent design into the classroom is at odds with America's pressing need to improve science education. They should continue to speak out in all available forums.

This argument has reverberated in US politics since at least 1925, when John Scopes, a high-school teacher in Dayton, Tennessee, was convicted and fined for teaching evolution. The fight will go on but science and reason can ultimately win.

with decent pension provisions, to ensure dignity and leisure for the old, while opening up job opportunities for the young. But there is a big difference between being forced to work to avoid penury and doing so because you love what you do. Most scientists' work is far more than just a job - it is a vocation, pursued with a passion that cannot be switched off overnight.

And nor should it be. Carl Friedrich Gauss may have surprised his school-teacher at the age of seven when he worked out the factorial of 100 in his head. But although the German mathematician made many of his important discoveries before he was 20 , he continued to make progress in a wide variety of fields into his seventies. Charles Darwin wrote two of his best books, The Descent of Man and The Expression of the Emotions in Man and Animals, in his sixties.

Science needs the energy and freshness of vision that youth can 
bring, but it can also benefit from the perspective and experience of age. The qualitative research that has been done on the matter reinforces the common-sense view that groups of people from a wide range of backgrounds are better at problem solving than are homogeneous ones. Science needs to take steps to keep the door open to exceptional older minds.

This must not, however, mean closing the door on younger researchers. In some countries - Germany and Japan spring to mind - the security and immovability of a ruling caste of established senior professors sometimes does just that. Even in countries with more flexible university systems, such as the United States, it has never been tougher for young scientists to win faculty positions (see Nature 422, 354-355; 2003).

At the same time, most countries face demographic and financial pressures that are forcing them to reconsider their general approach to mandatory retirement. Falling birth rates and higher life expectancy mean that there will soon be far fewer working people to support pensioners' income, from public or private sources. Poor stockmarket performance and inadequate provision for state pensions compound the problem. The subsequent discussion of higher retirement ages doesn't thrill the public. But in science, it should allow for a fuller consideration of measures that will tap the energy of older researchers who want to keep working.

It is time for policy-makers and university administrators to look more imaginatively at ways of structuring academic careers to introduce greater flexibility and alternative options. Just as science stands to benefit from arrangements that will better accommodate women with children, or attract more interest from ethnic minorities, it can benefit from active measures to help older researchers who still have what it takes.

Greater use of the 'emeritus professor' system, where researchers keep an association with an institution while drawing their salary from their pension, can tap the brains of older specialists who are no longer active in research. Research institutions and governments should also be searching for ways to accommodate those who want to remain active in research and have a contribution to make.

\section{Tale of two tigers}

\section{Aspirant research hubs in southeast Asia have enjoyed contrasting fortunes.}

W hen Malaysia and Singapore became politically distinct entities in 1965, a yawning chasm soon developed between the two nations' scientific performance - and it continues to grow.

Under the skilful tutelage of Philip Yeo, a businessman and former engineer, Singapore is creating one of the world's most dynamic research environments. The system built up by Yeo since he took control of the nation's science policy has given the country's biotechnology the promise of a bright future (see page 767). Despite some questions about the commitment of Singapore's government to free expression, the island nation has succeeded in attracting both leading scientists and substantial business investment from abroad, offering grants with few strings and a cosmopolitan research environment that is conducive to international collaboration.

Some concerns have been expressed about the reliance of Singapore's success on Yeo's own energy and influence. But there is ample evidence that he has put in place a meritocratic system that will comfortably outlive the oversight of one individual. In just two decades, Singapore has established itself as an important regional hub for biological research, with particular strengths in genomics and cancer research.

Malaysia's attempts to establish itself scientifically have been far less successful (see Nature 436, 620-621; 2005). The country has sought in vain to establish a biotechnology industry, the most conspicuous failure being the BioValley project near Kuala Lumpur. New independent universities, emphasizing their dedication to cutting-edge research, have been built after considerable political negotiation, but they are struggling to establish themselves as internationally competitive.

Part of Malaysia's problem lies in educational and hiring policies that favour native ethnic Malays, at the expensive of native ethnic Chinese and Indians, as well as foreigners. It is understandable that the Malaysian government wants to take measures to preserve the opportunities for a group that makes up the majority of its population, but which, by some measures, remains economically and socially disadvantaged.

But accusations abound that the existing system is not sufficiently meritocratic, and that personal connections often predominate in decision-making, with regard to both hiring opportunities and the distribution of grants. Science also enjoys insufficient autonomy within the Malaysian government. And in instances such as the BioValley project, investment has been showered on infrastructure, rather than on people.

Malaysia, of course, is not the only country in the region where research suffers from political mismanagement. China, Japan and others are also prone to over-investment in facilities, as opposed to personnel; difficulties in the fair evaluation of grants, and problems in fully engaging with outside scientists from neighbouring countries and further afield.

Singapore's success provides a useful model in this regard. It could also serve as a focal point

\section{"Singapore's success could serve as a focal point formorescientific collaboration in the region."} for more scientific collaboration in the region. East Asian countries have never found it easy to work together. The Asia-Pacific International Molecular Biology Network (www.a-imbn.org), for example, has sought for years to build a firmer foundation in the manner of the European Molecular Biology Organization, which helped to build the European Molecular Biology Laboratory in Heidelberg, Germany.

Singapore, with its recent track record of attracting top-notch researchers, would be the ideal location for any such regional collaboration. It could also act as a bridge between researchers in China, Japan and South Korea, where bitter rivalries have hamstrung such projects in the past. And it might enable Singapore to export some of the approaches which Yeo has so successfully championed in his own country. 